\title{
THE SOCIO-ECONOMIC DIMENSION OF INDUSTRY IN SUBREGIONS
}

\section{Abstract}

Industry is one of the key sectors of the economy, which affects a number of other areas as well as society and the environment. In its socio-economic dimension it has impact on the job market, wages, innovation, and the competitiveness of enterprises and territorial units.

The purpose of this article is to classify and assess the situation of 72 Polish subregions (NUTS-3) in terms of industrialisation as one of the components affecting the level and structure of subregional development. The classification was performed on the basis of employment structure and regional productivity data with reference to gross added value. Due to data availability the analysis was carried out based on the information about the activity of enterprises in PKD (Polish Statistical Classification of Economic Activities) sections B to F (including construction) in the years 2010-2014 and for selected aspects in 2015. The study applied classification methods (Ward method) and linear ordering (SDM with a common development model). The analysis allowed the author to identify classes of subregions presenting a particular industrial development profile (general, social or economic) and characterised by one development type in accordance with L. Klaassen's classification.

The conclusions resulting from the presented analysis indicate visible differences in the role played by industry in subregions as a regional employer (social aspect) or economic leader (economic aspect). The results of the change dynamics analysis pointed to a strengthening of the role of industry in subregions in terms of the economic aspect and a simultaneous decline in the importance of the social aspect (in this study related to jobs).

Keywords: industry, subregions (NUTS-3), classification, synthetic measure of development.

JEL Classification: O14, O18.

Beata Bal-Domańska, Wrocław University of Economics, Faculty of Economics, Management and Tourism in Jelenia Góra, Department of Regional Economy, Nowowiejska 3, 58-500 Jelenia Góra, Poland, e-mail: beata.bal-domanska@ue.wroc.pl 


\section{Introduction}

Development is defined as a dynamic phenomenon, covering many areas, which are expected to develop and transform in terms of quality and structure. Regional development is considered a complex phenomenon that integrates various activities within a particular territory. According to the proposal by Klasik and Kuźnik (2001), regional development consists of the following components:

- economic growth and employment,

- increased well-being and life quality of the population,

- technological development and innovation,

- restructuring of economic activities,

- development of services and social resources,

- increase in occupational, social and spatial mobility,

- development of institutional infrastructure,

- improved quality of the environment,

- enrichment of regional identity and integration processes.

Development processes occur in different regions in various ways. This is influenced by the current development level, the availability of resources and the management style. The differences in capital provision for regions, including human capital and also other production factors, jointly decide about their competitive power.

When assessing developmental changes in a cross-section of territorial units, attention should be paid to both the position of units relative to others and the changes that are occurring. The position of a unit allows one to assess the archived level of competitiveness and current availability of resources. Changes, in turn, have an impact on the future competitive position and possibilities for adaptability.

These two components - the level of development and changes represent two basic assessment criteria for the processes occurring in territorial units. They are fundamental to the classical typology of regions proposed by L. Klaassen (1965) (after Szymla 2005). He distinguishes a four-level classification of regions, simultaneously taking into account their development level in relation to the pace of occurring changes (where the national average is the reference point). In line with this classification, four classes of regions can be distinguished:

- WW - prosperity area, better developed and faster developing regions,

$-\mathrm{nn}$ - distressed area, less developed and slower developing regions, 
- nW - distressed area in the process of development, less developed and faster developing regions,

- Wn - declining prosperity area, better developed and slower developing regions.

The results of the conducted analysis are presented below. The analysis was focused on the position of industrial enterprises in 72 Polish subregions. The activity of enterprises, including industrial ones, is reflected in many social aspects of regional development (e.g. the consumer goods market, job market, wage levels and thus the purchasing power of society), economic aspects (GDP creation), environmental aspects (e.g. emissions, noise, waste, consumption of resources) and also technological aspects - the development of technology and knowledge application, thus developing the efficiency of the economy (economic, environmental, social).

One consulting company (Poland 2025... 2015) presents Poland as an EU growth engine and recognises that "the Polish economy has doubled in size, as measured by real GDP. (...) Poland was the only EU country to avoid recession as a result of the global financial crisis and is today the eighth-largest EU economy", and further "(...) despite the progress, Poland's comparative labour productivity in 2012 remained low in a few key sectors (e.g. mining, energy, agriculture)". The authors of this report consider the process manufacturing sector to be built on the proven advantages of the economy with the potential to become a major engine of growth. This sector covers such segments as automotive, food processing, furniture, textiles and chemicals.

In the aforementioned study, industry is presented as one of the basic sectors of the economy, producing goods and creating a job market. The study is focused on the characteristics of the spatial diversification of industrial enterprises' activities regarding an assessment of the level of involvement in a given area as well as the dynamics and direction of the changes under way.

Based on recognising the structure, spatial differentiation and activity range of industrial enterprises, it is possible to reliably identify the strategic assumptions of development. The statistical perspective allows for more precision in defining the profile and spatial dependence (diffusion effect) and specifying the strengths and weaknesses of subregions. Because of this it is possible to carry out development-oriented activities which can support the regional strengths that determine competitive advantages and all other positive aspects of development along with the simultaneous elimination of the weaknesses and negative effects of changes. Having taken 
into account the dynamics in the conducted analysis, it is also possible to observe structural changes, which are perceived as the basic component of development. In the opinion of Karpiński (1986), "the deeper the changes in structure the faster the pace of development". Thus, the causative nature of structural changes was recognised. It should, however, be emphasised that this is a mutual relationship and the level of development also influences the possibilities of structural transformations.

The purpose of the analysis is to identify classes of subregions (NUTS-3) in terms of industrial enterprise activity in two aspects:

- social, covering employment in industry,

- economic, focused on product volume produced in a subregion, identified using gross added value.

Taking the aforementioned two aspects into account allowed the author to assess industry in terms of its direct input in economic growth and employment (listed as the first element in Klasik and Kuźnik's definition of development (2001)). The analysis applied taxonomic methods based on the data covering the 2010-2014 period. The conducted analysis allowed questions to be answered about:

- the role of industry and construction in subregions in terms of social and economic aspects in the following sections: C, BDE and F in 2014/2015,

- the development profiles of subregions in terms of the industrial development level in accordance with social and economic priorities in 2014,

- the changes in the industrial development level in subregions in 2014 compared to 2010 for industry as a whole and for social and economic aspects separately,

- the classification of subregions by classes according to Klaassen's typology and their spatial distribution for industry as a whole and for each of the aspects separately. Their definition allowed the author to assess the level and type and also the profile of industrial development in subregions.

\section{The Scope and Procedure of the Study}

Identification of the research problem and the data available in public statistics allowed the author to propose a set of indicators to diagnose the activity of enterprises in subregions. The assessment of industrial level in subregions was based on indicators taking into account a total of 5 sections of the industrial sector: section $\mathrm{C}$ - industrial processing; $\mathrm{B}$ - mining and quarrying; D - production and supply of electricity, gas, steam, hot water and air for air-conditioning systems; E - water supply, sewage and waste 
management and reclamation related activities; and additionally $\mathrm{F}$ construction.

The analysis was focused on both the economic and social role of industry in the region. The phenomena within the scope of industrial development in subregions were measured using two indicators in two aspects:

- social aspect - the share of employment in sections B, D, E, F in total employment $(E)$ in $\%$,

- economic aspect - regional productivity, i.e. gross added value $(G A V)$ produced by the sections of the industry and construction sector $(\mathrm{B}, \mathrm{C}, \mathrm{D}, \mathrm{E}$, F) in PLN calculated for 1 person of working age.

While defining the $G A V$ indicator, in terms of its economic aspect, the traditional productivity measure structure was modified. Modified $G A V$ refers to total employment in the subregion instead of employment in the sections of industry and construction. By constructing the indicator in this way it is possible to avoid distortions in the picture of subregions where high productivity (measured as gross added value per 1 employee in industry) is obtained by a relatively small group of industrial enterprises playing a minor role in the scale of the region.

The analysis aimed to achieve two goals: (1) to identify subregions characterised by a similar industrial structure (which was carried out using classification methods) and (2) to assess positions and changes in time related to the level of industrial development in subregions (for which a synthetic development measure $S D M$ was used). The following research procedure was adopted to achieve these goals:

1. Collecting statistical data for subregions in the years 2010-2014 and 2015.

2. Conducting a preliminary data analysis.

3. Preparing the classification of subregions in terms of industrial structure based on economic and social aspects regarding the indicator levels achieved in 3 groups created by: C - industrial processing, B, D, E other industrial sectors, and $\mathrm{F}$ - construction. A distance matrix was applied in the classification based on Euclidean distance and one of the cluster analysis hierarchical methods, i.e. Ward's agglomeration method (cluster trees) (Ward 1963). The calculations were made in the STATA program.

4. Defining the value of the synthetic development measure with the common model for the years 2010-2014 for each aspect separately (SDM $G A V$ and $S D M_{-} E$ ) and jointly $(S D M)$. The non-model linear ordering method was used to specify $S D M$ - standardised sums method. SDM values were determined as the mean value of industrial development 
indicators after prior transformation using the zero unitarisation method (Taksonomiczna analiza... 2000, Walesiak 2006).

5. Determining weights for each of the variables: it was assumed that both the social and economic aspects are of the same significance and were assigned a 0.5 weight. Ultimately, the general $S D M$ was determined as an $S D M$ weighted average for the $E$ variable and for $G A V$ and took the following form:

$$
S D M=0.5 S D M_{-} E+0.5 S D M_{-} G A V
$$

6. The classes of subregions were formed to identify groups of subregions by the dominant role of industry in terms of economic or social aspects, based on the median value of the $G A V$ and $E$ variables. The classes were defined according to the median criterion (median value $S D M_{-} G A V_{w i}=$ $=0.07$ and $S D M_{-} E=0.2$ ) as follows:

- socio-economic priority subregions - characterised by a relatively high level of industry involvement, measured by both the $G A V$ and $E$ variables (both variables higher than the median),

- subregions with economic priority - presenting a relatively high level of industry involvement measured by $G A V$ and a low employment level in industry $E\left(S D M_{-} G A V_{w i}>0.07\right.$ and $\left.S D M_{-} E<0.2\right)$,

- subregions with social priority - a relatively low level of industry involvement measured by $G A V$ and a high employment level in industry $E$ $\left(S D M_{-} G A V_{w i}<0.07\right.$ and $\left.S D M_{-} E>0.2\right)$,

- subregions with a low level of industry development - minor industry involvement measured by both $G A V$ and a low level of employment in industry $E$ (both variables lower than the median).

7. $S D M$ values and changes in them allowed the regions to be grouped into four classes in line with the classical typology of regions proposed by L. Klaassen. The division was based on the median value for the level of general SDM in 2014 and changes in SDM in 2014 compared to 2010. The classes were defined in the following way (see above): WW - prosperity area, $\mathrm{nn}$ - distressed area, nW - distressed area in the process of development, $\mathrm{Wn}-$ declining prosperity.

One of the more important elements in the construction of the classes of subregions by type of development (according to Klaassen) was to determine the division boundary. In the majority of cases the median value of the measure was used, which allowed subregions to be divided according to the average level achieved by half of the subregions. However, in the case of changes in the synthetic development measure regarding the social 
aspect $\left(S D M_{-} E\right)$, this criterion proved insufficient. As many as 53 out of 72 subregions recorded a decline in $S D M_{-} E$ in 2014 compared to 2010. As a result, the median value was negative and using it for the division into developing regions turned out to be useful. In this case, the a priori specified value of 0.01 was used, which allowed the author to identify those subregions which featured minor or negative changes and also ones which recorded a small but - when compared with the others - noticeable improvement (developing subregions). Ultimately, the adopted median value for $S D M_{-} E$ was 0.21 , and for the changes in SDM_E: 0.01 . Unfortunately, only 7 regions exceeded the improvement level in the social aspect (amounting to 0.01). For the general $S D M$, a median value equal to 0.3 was adopted, whereas for the changes in general $S D M$ : 0.02. In the case of classification regarding the economic aspect, the median value for $S D M_{-} G A V$ was 0.08 and for the changes in SDM_GAV: 0.03 .

The study covered 72 Polish subregions for industry and construction jointly. The basic analysis period covered the years 2010-2014. Due to data availability, the first part of analysis, covering the structure of industry in subregions, was presented for one year. In the case of the economic aspect, based on regional productivity, it was 2014, whereas for the social aspect, based on employment structure, the data originated from 2015. The next section presents an analysis of the industrial development level taking into account the dynamics of changes in 2014 compared to 2010.

\section{The Results of the Importance of Regional Industrial* Diversification in Subregions}

\subsection{The Structure of the Industrial Sector and Construction in Subregions}

The assessment of subregions in terms of industrial development, regarding regional productivity and the development of the regional job market, was carried out by assessing industrial structure in the social and economic aspects for selected groups of sections: $\mathrm{C}, \mathrm{BDE}$, and $\mathrm{F}$. The classification of subregions allowed subregions with a similar industrial development structure to be identified.

For both aspects, subregions were divided into four classes. The number of classes was adopted a priori based on a dendrogram analysis. In the case of the social aspect, the major differentiating feature was industrial processing. Moreover, in one of the classes a visibly large role was played by

I * Construction is included wherever industry is concerned. 
sections BDE, including mining. The level of employment in construction did not differ much between classes.

The class characterised by well-developed BDE sections was class 2, "processing-mining", which included only 3 subregions identified in terms of an extensive mining function (Figure 1). These regions are as follows: Legnicko-Głogowski, Rybnicki and Tyski. The subregions covered by class 1 are placed at the opposite end, i.e. "low industrialised" (in which processing and mining played a minor role on the job market). This class included all subregions representing entire cities with powiat (district) status and four subregions from eastern Poland: Bialski, Białostocki, Chełmsko-Zamojski and Lubelski. The limited role of industry in cities with powiat (district) status is associated with their function as regional centres dominated by services. The most numerous group of subregions was made up of those formed by class 3, "with developed processing sector". This class included 44 units, in which industrial processing was an important element of the job market, providing employment for $20 \%$ to $25 \%$ of persons employed.
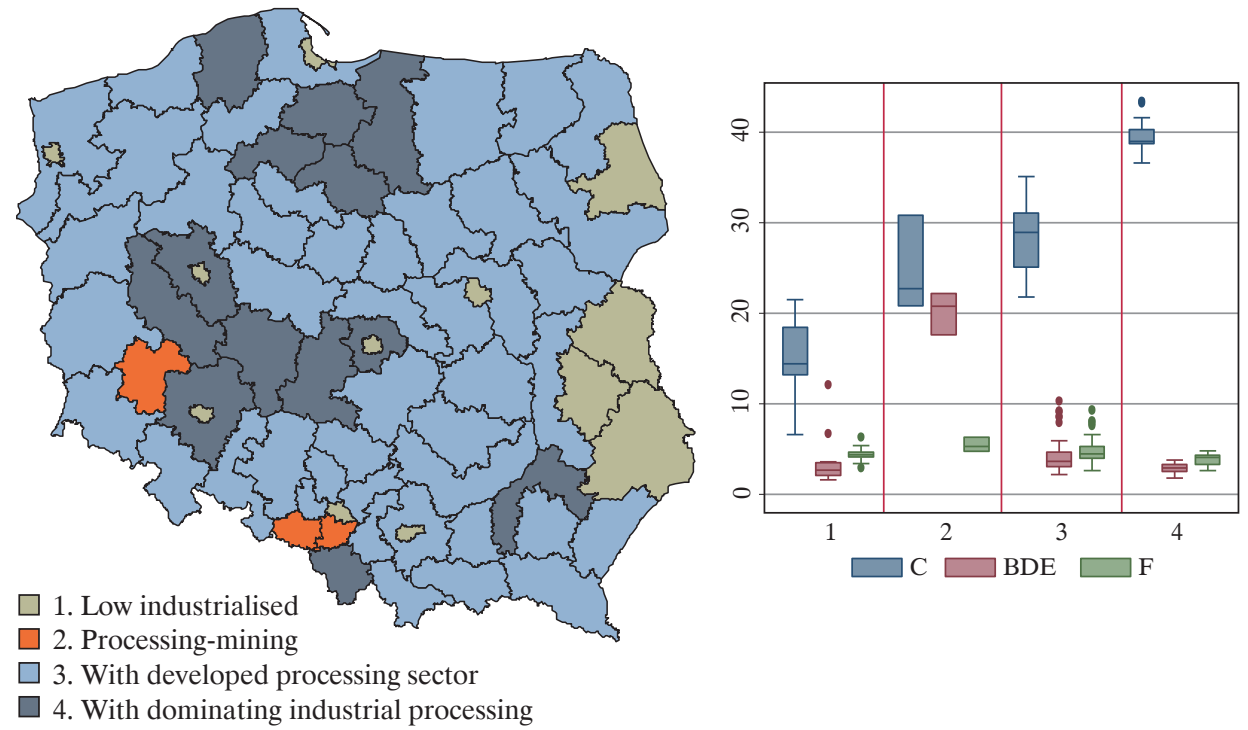

Fig. 1. Classes of Subregions by the Share of Employment in Sections C, BDE and $\mathrm{F}$ in Total Employment in 72 Subregions (Left Side) and the Distribution of Indicator Values in Classes in \% (Right Side) in 2015

Source: author's compilation based on data from the Local Data Bank of Statistics Poland. 
Having analysed the situation of industry and construction in the economic aspect, a slightly different situation becomes noticeable (Figure 2). Similarly to the social aspect, the largest differences in classes defined in the economic aspect were visible in the development level of processing industry (section C). Class 3, characterised by "dominant processing", covered only two subregions: Legnicko-Głogowski and Płocki.
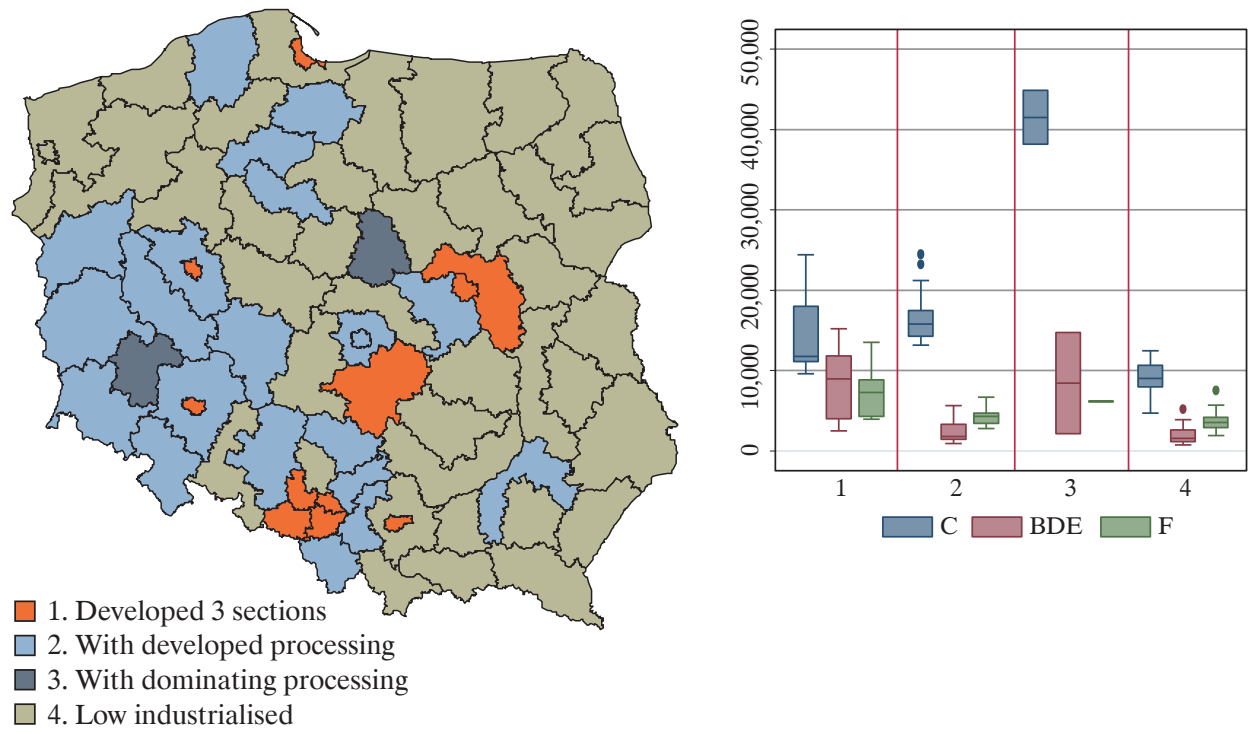

Fig. 2. Classes of Subregions in Terms of Regional Productivity in Sections C, BDE and $\mathrm{F}$ in 72 Subregions (Left Side) and the Distribution of Indicator Values in Classes in PLN for 1 Person of Working Age (Right Side) in 2014

Source: author's compilation based on data from the Local Data Bank of Statistics Poland.

Class 1, i.e. "three sections developed" and 2, "with developed processing", should be recognised in terms of the economic aspect as classes whose subregions obtain the major part of regional $G A V$ from industry processing enterprises, and in case of class 1 , also from the construction and BDE sections. Class 1 was made up of 11 subregions characterised by high regional productivity in all three sections $(\mathrm{C}, \mathrm{BDE}, \mathrm{F})$. The majority of them were cities with powiat (district) status and capital subregions (Tri-City, Warszawski, Katowicki) as well as the Piotrkowski subregion. Class 2 is numerous and covers 21 units located mainly in the south-western belt of Poland, in the area of Łódź and Warsaw, and in Bydgoszcz, Toruń and 
Słupsk. The other 38 units were assessed as subregions presenting relatively low regional productivity in sections $\mathrm{C}, \mathrm{BDE}$ and $\mathrm{F}$ and were included in class 4., i.e. "low industrialised").

\subsection{The Level and Dynamics of the Industrial Sector and Construction}

This part of analysis presents the assessment results of industrial and construction development in subregions in terms of social and economic aspects taking into account the level, diversification and dynamics of changes. Figures 3 and 4 present the range of input values adopted by the analysed $G A V$ and $E$ indicators in the years 2010-2014.

The level of employment in industry was differed significantly between subregions - in 2014 from 13\% up to almost 49\%. Larger disproportions were visible in the group of subregions with an above median share of employment in industry and construction. In $50 \%$ of subregions the value of the $E$ indicator exceeded $27.9 \%$ (median value), reaching a level higher by even 21 percentage points for selected units, whereas in the case of the remaining $50 \%$ of units the level was lower by 14 percentage points. At the same time, a negative tendency for each of the discussed statistics was observed (min. value, median and max. value) confirming the decline in the role of industry on the regional job market.

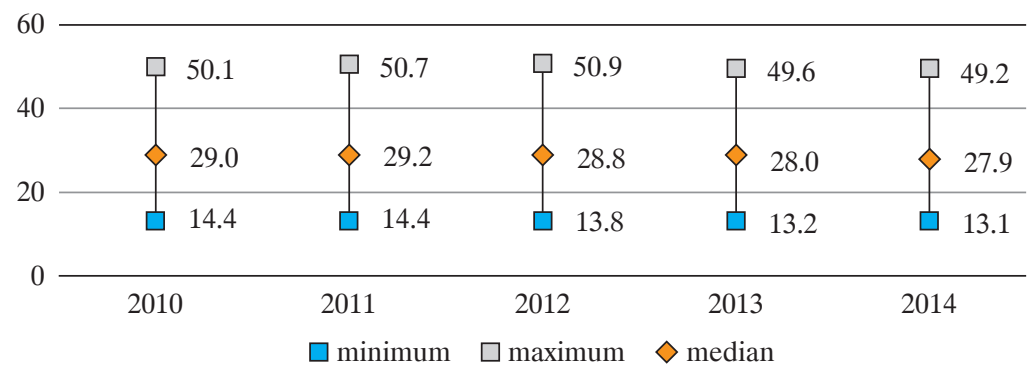

Fig. 3. Employment in Industry and Construction as a Share of Total Employment (\%) in 72 Subregions in the Years 2010-2014

Source: author's compilation based on data from the Local Data Bank of Statistics Poland.

The differences are even more extensive in the case of the $G A V$ indicator level for low and high values. The median is approximately twice higher than the minimum value, whereas the maximum value in 2014 was over three times higher than the median. Different tendencies in time characterised the presented statistics. After an increase in 2011, 
maximum values declined, while the median and minimum values showed an improvement in the situation of subregions. The higher pace of median value improvement should be regarded as a very positive symptom, as it went up by approximately $30 \%$ in 2014 compared to 2010 (for the minimum value it was approximately $25 \%$ ), which suggests that some subregions recorded a relatively fast increase.

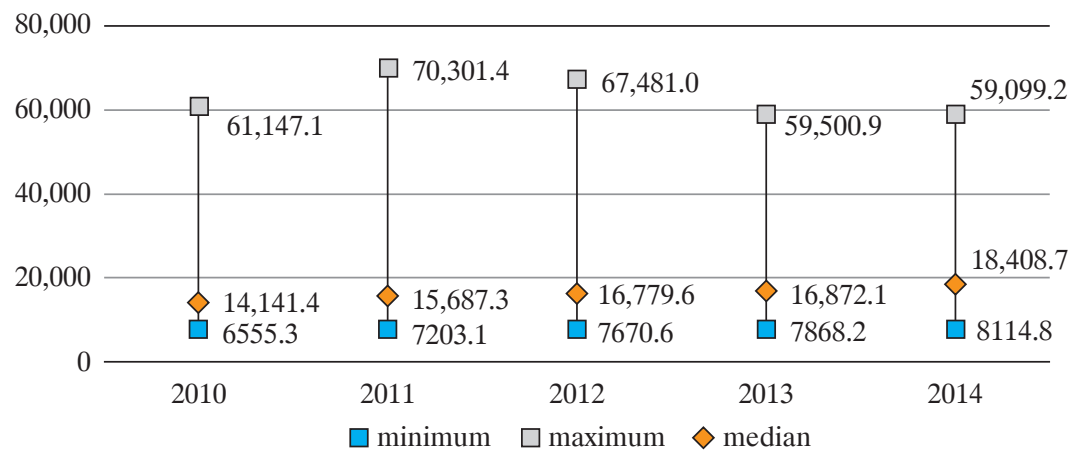

Fig. 4. The Values of Regional Productivity (in PLN per 1 Person of Working Age) in 72 Subregions in the Years 2010-2014

Source: author's compilation based on data from the Local Data Bank of Statistics Poland.

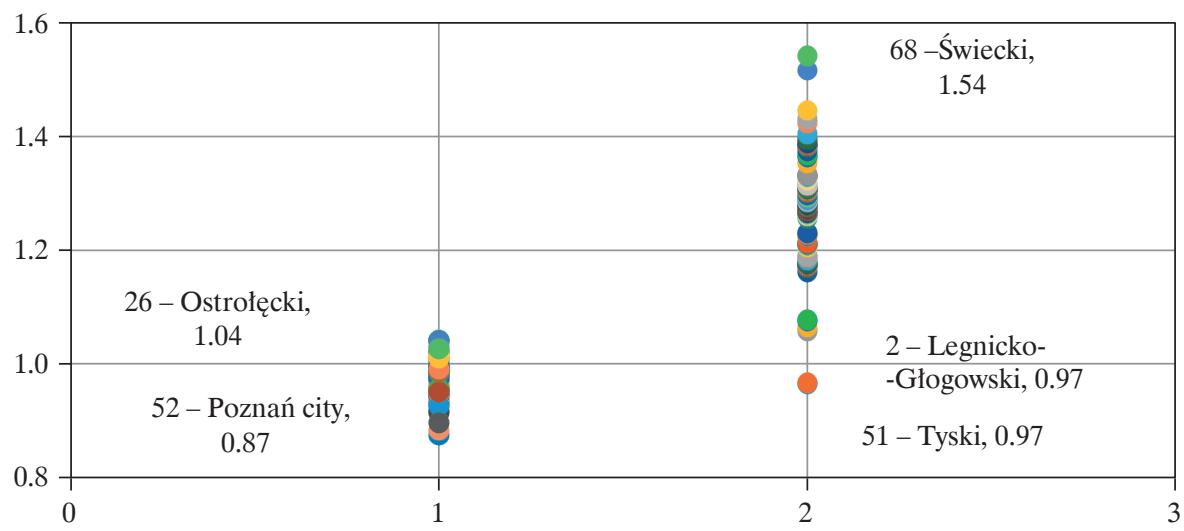

Fig. 5. Changes in Regional Productivity (Marked 2 on the $x$ Axis) and Employment Share (Marked 1 on the $x$ Axis) in Industry and Construction in 72 Subregions in 2014 Compared to 2010

Source: author's compilation based on data from the Local Data Bank of Statistics Poland. 
Figure 5 presents changes in the values of the $G A V$ and $E$ indicators in 2014 compared to 2010. The share of employment in industry and construction $(E)$ in 53 subregions in 2014 was lower than in 2010. The highest decline was recorded in Poznań and amounted to 13\%, whereas in the Ostrołęcki subregion the largest recorded increase was only $4 \%$. An increase in the importance of industry and construction on the regional job market was recorded in 19 subregions only.

The highest increase in regional productivity $(G A V)$ was observed in the Świecki subregion and was as high as 54\%. Only two subregions recorded a drop in regional productivity - by as little as $3 \%$ only.

Synthetic measures of development were defined in order to compare industrial and construction levels in subregions. The general measure $(S D M)$ was established on the basis of partial values in the social $\left(S D M_{-} E\right)$ and economic (SDM_GAV) aspects. Their preliminary analysis allowed the following conclusions to be presented:

- A small group of subregions achieved visibly higher results than the other subregions, i.e. Tyski and Glogowsko-Legnicki. These subregions took the position of leaders in the economic aspect, and in case of the Tyski subregion also in the social aspect. The group of economic aspect leaders also includes the Płocki subregion. It should be emphasised that the position of leaders deteriorated considerably in the last analysed years, i.e. in 2013 and 2014,

- The differences in development level regarding the economic aspect are larger than in the case of the social aspect,

- The changes in development level occurred differently - in terms of the social aspect, a gradual decline in the situation was observed in many subregions, which indicated the decreasing role of the industrial and construction sectors as job providers. As far as economic aspect is concerned, an improvement was observed in subsequent years, showing the higher productivity of this sector. These observations are confirmed by the values of the correlation coefficient between $S D M_{-} E$ and $S D M_{-} G A V$, which was relatively low and continued the decreasing trend in the following years (Table 1).

Table 1. The Values of the Correlation Coefficient of Synthetic Development Measures in the Social and Economic Aspect (SDM_E and SDM_GAV)

\begin{tabular}{c|c|c|c|c|c}
\hline Specification & 2010 & 2011 & 2012 & 2013 & 2014 \\
\hline$S D M_{-} G A V$ and $S D M_{-} E$ & 0.480 & 0.469 & 0.472 & 0.469 & 0.457 \\
\hline
\end{tabular}

Source: author's compilation based on data from the Local Data Bank of Statistics Poland. 
Figure 6 presents the spatial distribution of subregions which show both a high level of industrial development in the economic and spatial aspect as well as ones which recorded a high position in one aspect only compared to other subregions. The regions were qualified to a particular group if they achieved s partial $S D M$ value exceeding the median $\left(S D M \_G A V>0.07\right.$; $\left.S D M_{-} E>0.2\right)$. The regions which, in both aspects, achieved indicators higher than the median were referred to as the industrial ones.

The regions characterised by a developed industrial sector in both aspects were located in the south-western and central part of the country and in part comprised the Podkarpackie, Pomorskie and Kujawsko-Pomorskie voivodships. The Tarnobrzeski and Warszawski wschodni subregions were the only areas presenting high industrial level in the east of the country. A total of 24 such regions were identified in 2014. As was stated by Kudełko (2016), "in comparison with other Polish regions, the regions of Eastern Poland are less industrialised. Industry plays the most important role in the Podkarpackie Voivodeship, whereas in the Lubelskie Voivodeship its importance is least significant. The leading industry domains in which the analysed regions can develop and become competitive include: food processing, the furniture industry, ceramics and other non-metallic mineral products, motor vehicles and chemical products".

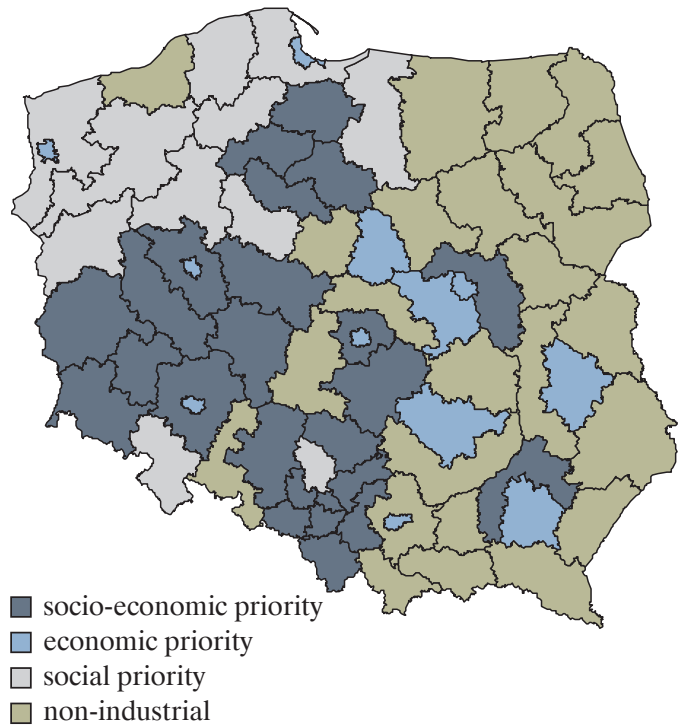

Fig. 6. Profiles of Subregions by Type of Industrialisation in 2014

Source: author's compilation based on data from the Local Data Bank of Statistics Poland. 
A special position in the conducted analysis was achieved by cities with powiat (district) status constituting independent subregions and also by selected subregions in central Poland (e.g. concentrated around Warsaw). They achieved very good results for regional productivity and at the same time did not play the role of an important employer on the regional job market. These 12 subregions were qualified among those presenting a distinctive economic priority (Figure 6).

The third group of 12 subregions is made up of those offering a relatively large number of jobs on the regional market, and despite that their regional productivity was assessed as low, thus their importance as economic centres was small. This group included subregions located in the north-western part of the country and in Wałbrzyski and Bytomski in the southern part (Figure 6).

In the case of 9 units, very large differences in the social and economic aspects were recorded, and for many units the difference exceeded 25 positions (Table 2). The Płocki subregion was one of the units in this group, which in the overall ranking achieved a high third place and which, as an employer on the regional market, was ranked at a low 41st position but simultaneously played the role of one of the leaders (2nd position) in terms of regional productivity. The largest differences in industrial development, regarding the social and economic aspect, were observed in the subregion covering the area of the capital city of Warsaw. This subregion should be included among areas presenting the highest productivity levels (6th position), along with the insignificant importance attributed to industry and construction on the regional job market (72nd position). This situation was present in all cities representing independent subregions (Table 2 and Figures 1 and 2). It is determined by the employment structure, which in capital subregions is, to a large extent, connected with services.

A large group (24 subregions) comprised subregions in which the industrial function was not identified on a level higher than the median for $S D M_{-} G A V$ and $S D M_{-} E$. These subregions were predominantly located in the east of Poland and in its central belt. The lowest level of industrial development was characteristic of the following subregions: Sandomiersko-Jędrzejowski, Przemyski, Bialski and Chełmsko-Zamojski.

Changes in the level of industrial development were noticed in the 20102014 period. Many regions saw their situation deteriorate in subsequent years. In 2014, a deterioration in general industrial development was observed in 9 subregions (Figure 7, left side) compared to 2010. In another 9 subregions a significant improvement was recorded. In the case of the 
remaining subregions, only a small improvement or no change was observed. As mentioned earlier, particularly unfavourable changes were found in terms of employment in industry and construction. A decline in employment share in the analysed sections was recorded in as many as 53 subregions, whereas a drop in regional productivity was recorded in only two.

Table 2. The Positions of Selected Subregions in the Social and Economic Aspect in 2014 (the Difference in Positions over 25 Places)

\begin{tabular}{|c|c|c|c|c|}
\hline Subregion & $\begin{array}{c}\text { General } \\
\text { Development } \\
\text { Level }\end{array}$ & $\begin{array}{c}\text { Economic } \\
\text { Aspect }\end{array}$ & $\begin{array}{l}\text { Social } \\
\text { Aspect }\end{array}$ & $\begin{array}{l}\text { Difference in } \\
\text { Positions in } \\
\text { the Social and } \\
\text { Economic } \\
\text { Aspect }\end{array}$ \\
\hline \multicolumn{5}{|c|}{ Social Aspect Dominance } \\
\hline 72 - Chojnicki & 38 & 63 & 28 & -35 \\
\hline 54 - Elbląski & 26 & 53 & 18 & -35 \\
\hline 64 - Szczecinecko-Pyrzycki & 39 & 65 & 32 & -33 \\
\hline $55-$ Ełcki & 52 & 68 & 39 & -29 \\
\hline 7 - Grudziądzki & 33 & 52 & 26 & -26 \\
\hline $31-$ Nyski & 44 & 62 & 37 & -25 \\
\hline \multicolumn{5}{|c|}{ Economic Aspect Dominance } \\
\hline 16 - Łódź city & 37 & 19 & 45 & 26 \\
\hline $65-$ Szczecin city & 58 & 33 & 60 & 27 \\
\hline 30 - Warszawski zachodni & 36 & 13 & 48 & 35 \\
\hline 43 - Trójmiejski & 43 & 17 & 55 & 38 \\
\hline $70-$ Płocki & 3 & 2 & 41 & 39 \\
\hline 5 - Wrocław city & 50 & 16 & 66 & 50 \\
\hline 21 - Kraków city & 48 & 15 & 65 & 50 \\
\hline 62 - Poznań city & 35 & 5 & 61 & 56 \\
\hline 28 - Warsaw capital city & 53 & 6 & 72 & 66 \\
\hline
\end{tabular}

Source: author's compilation based on data from the Local Data Bank of Statistics Poland.

In the context of the conducted analysis, it is interesting to find out whether the regions recording a decline represent those characterised by an initially low or high development level. The subregions' classification results, in line with Klaassen's proposal, are presented in Figure 7 (right side).

Twenty-two subregions, representing "prosperity area" (developing leader) status, were identified in the general classification (based on both selected variables combined in $S D M$ ). These regions were characterised 
by a high level of industrial and construction development and were continuously improving their position at a level above the median of the general SDM changes. They are located in the western and central part of the country. Only 3 of them - Słupski, Kaliski and Świecki - also represented the status of leaders in both analysed aspects, i.e. social and economic.

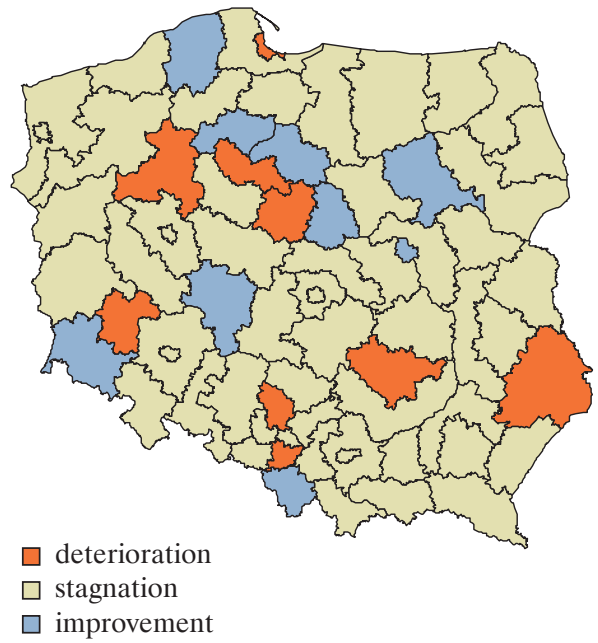

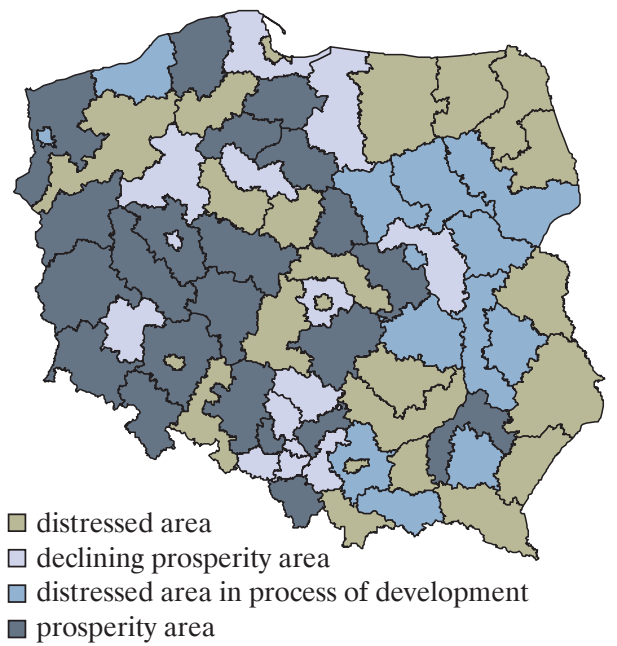

$\square$ prosperity area

Fig. 7. Changes in SDM Value in 2014 Compared to 2010 (Left) and Classes of Subregions in Accordance with Klaassen's Typology in 2014 (Right)

Source: author's compilation based on data from the Local Data Bank of Statistics Poland.

The second group that recorded a positive situation comprised 13 subregions presenting a low level of general development in industry and construction, albeit with an improving situation. In these regions, referred to as "distressed areas in the process of development", in spite of a low initial level of industrial development, one of the higher development measure increases was observed (above the median of the general SDM changes). These subregions are located in the east-central part of the country and surround the subregion of Warsaw capital city, and in the area of Kraków city, whereas one subregion from this group is located in the north (Koszaliński).

The situation of 14 subregions raises concerns. These regions were going through a period of stagnation and presented a high level of industrial and construction development, but ceased to develop during the analysed period (“declining prosperity areas"). This group included such ranking leaders 
as the Tyski and Legicko-Głogowski subregions and also Poznań city, the Katowicki subregion and the adjacent ones, and subregions that neighbour large cities: Gdański, Łódzki, Bydgosko-Toruński, Częstochowski, Warszawski Wschodni, Pilski and Elbląski.

The most difficult situation was characteristic of subregions that featured a low level of industrial development and, at the same time, did not show any improvement. There were 23 distressed areas, i.e. $32 \%$ of units. In the case of 13 of these - Chełmsko-Zamojski, Sandomiersko-Jędrzejowski, Bialski, Inowrocławski, Ełcki, Nowotarski, Suwalski, Krośnieński, Przemyski, Nyski, Włocławski, Tarnowski and Białostocki - the difficult situation concerned both analysed aspects, i.e. economic and social. In the remaining ones, despite a low general $S D M$ assessment, at least in one of the areas the level of changes can be considered moderately positive compared to other units covered by the analysis.

Figure 8 shows classes of regions grouped in accordance with Klaassen's proposal in both analysed aspects: social (left side) and economic (right side).
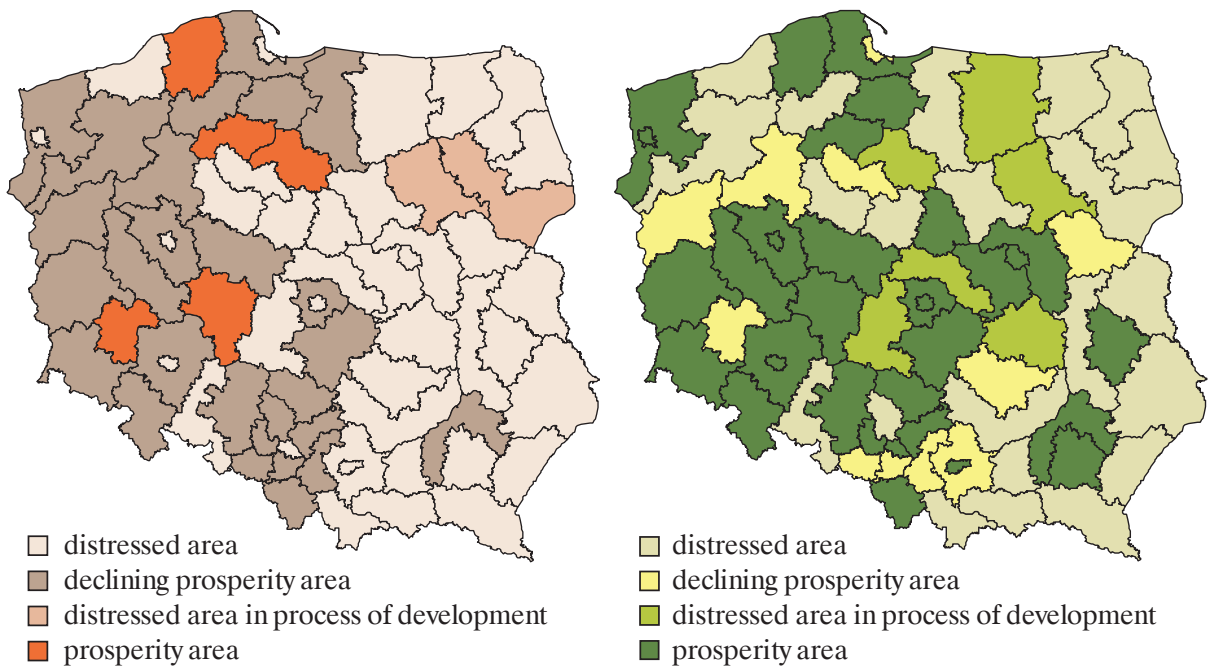

Fig. 8. Classes of Subregions in Line with Klaassen's Typology in the Social (Left) and Economic (Right) Aspect

Source: author's compilation based on data from the Local Data Bank of Statistics Poland.

As regards the social aspect, the class of "distressed area" regions included as many as 38 units, predominantly cities with powiat (district) 
status and subregions in the central and eastern part of Poland. A large group of 27 subregions comprised the class of "declining prosperity areas", mainly located in the western part of the country. Only seven subregions, forming "distressed area in process of development" and "prosperity area" groups, could be assessed positively, two of them due to an observed improvement in their situation in recent years (Łomżyński and Ostrołęcki). Only five subregions recorded a high position compared to others in terms of the regional job market they created, which was also, in the years 2010-2014, continuously strengthened ("prosperity area"). These were the following subregions: Legnicko-Głogowski, Grudziądzki, Słupski, Kaliski and Świecki.

The situation of subregions in terms of their spatial distribution in the economic aspect was different. In this case, a less numerous although still large group of subregions (33) presenting the least favourable situation was visible. These are referred to as "distressed areas", i.e. areas in which the pace of change in 2014 compared to 2010 was minor or negative and which in 2014 were simultaneously included in the group of subregions with the lowest regional productivity level. These subregions are mainly located along the eastern border and in the following voivodships: Zachodniopomorskie, Kujawsko-Pomorskie and Małopolskie. In the years 2010-2014, an improvement in the situation was recorded in 6 subregions only, included in the group of subregions characterised by low productivity. The group of subregions called "distressed areas in the process of development" covered: Olszyński, Sieradzki, Skierniewicki, Radomski, Ostrołęcki and Grudziądzki. In the case of 11 subregions, in which industry and construction represented a significant source of gross added value, the years 2010-2014 were lacking progress or even recorded a drop in regional productivity. In this class, the decline concerned only two leaders in the ranking of industrial activity the Tyski and Legnicko-Głogowski subregions. This group also covered a few subregions from the Śląskie voivodship and single regions from other voivodships.

\section{Conclusions}

The analysis of the spatial diversification of industrial development in subregions confirmed the existing differences in the level of development in eastern and western Poland that are highlighted in various studies and analyses. In the summary of the presented research results, the following should be emphasised: 
- Among the analysed groups of sections (C, BDE and F) in industry and construction, the industrial processing sector plays the dominant role in subregions as a provider of jobs and $G A V$.

- The subregions that achieved the best results for the analysed indicators were those characterised by a well-developed mining sector (included in the assessed group of B, D and E sections).

- Cities with powiat (district) status play a relatively small role on the regional job market in terms of employment in industry.

- Distinctive development profiles of subregions were visible in terms of industrial development in line with social and economic priorities in 2014; both aspects were well-developed, mainly in the voivodships of western and central Poland.

- The tendency to reduce the importance of industry as an employer, which persists in many subregions, is a cause for concern. This situation was still observed several years after the 2008 crisis, which suggests that these negative phenomena have persisted not just as the direct effect of the crisis, but also due to other unfavourable phenomena.

- Only a few of the subregions with a low development level recorded an improvement in their situation in recent years, particularly if the assessment covered only one aspect (in the case of the social aspect this concerned 2 units, and in the case of economic aspect -6 units). The situation was slightly better for the cumulative effect measured in the overall SDM. The improvement of backward regions (distressed areas in the process of development) mainly concerned the area surrounding the subregions of the second ring of Warsaw.

\section{Bibliography}

Karpiński, A. (1986) Restrukturyzacja gospodarki $w$ Polsce $i$ na świecie [Economic restructuring in Poland and abroad]. Warszawa: PWE.

Klaassen, L. (1965) Area Economic and Social Redevelopment: Guidelines for Programmes. Paris: OECD.

Klasik, A. and Kuźnik, F. (2001) "Konkurencyjny rozwój regionów w Europie” [Competitive development of regions in Europe] in Z. Szymla (ed.) Konkurencyjność miast i regionów [The competitiveness of cities and regions]. Kraków: Wydawnictwo Akademii Ekonomicznej w Krakowie.

Kudełko, J. (2016) "Rola przemysłu w rozwoju regionów Polski Wschodniej". Międzynarodowe uwarunkowania rozwoju przemystu [International conditions for the development of industry]. Prace Komisji Geografii Przemystu Polskiego Towarzystwa Geograficznego 30 (3): 147-58. 
Poland 2025: Europe's New Growth Engine (2015) McKinsey\&Company, www.mckinsey. com.

Szymla, Z. (2005) "Podstawy badań rozwoju regionalnego". Zeszyty Naukowe Wyższej Szkoty Ekonomicznej w Bochni 3: 101-11.

Taksonomiczna analiza przestrzennego zróżnicowania poziomu życia $w$ Polsce $w$ ujęciu dynamicznym (2000) A. Zeliaś (ed.). Kraków: Wydawnictwo Akademii Ekonomicznej w Krakowie.

Walesiak, M. (1986) "Ocena zmian w wynikach klasyfikacji województw Polski ze względu na gałęziowy poziom oraz profil uprzemysłowienia w okresie 1975-1980”. Prace Naukowe Akademii Ekonomicznej we Wroctawiu 360: 83-109.

Walesiak, M. (2006) Uogólniona miara odlegtości w statystycznej analizie wielowymiarowej. Wrocław: Wydawnictwo Akademii Ekonomicznej we Wrocławiu.

Ward, J. H. Jr. (1963) "Hierarchical Grouping to Optimize an Objective Function". Journal of the American Statistical Association 58(301): 236-44, https://doi.org/10.1080/ 01621459.1963.10500845.

\section{Abstract}

\section{Spoleczno-gospodarczy wymiar przemysiu w podregionach}

Przemysł stanowi jeden z podstawowych sektorów gospodarki, który oddziałuje na szereg innych jej obszarów, a także na społeczeństwo i środowisko. W obszarze społeczno-gospodarczym kształtuje rynek pracy, poziom wynagrodzeń, innowacyjność i konkurencyjność przedsiębiorstw oraz jednostek terytorialnych.

Celem artykułu jest klasyfikacja i ocena sytuacji 72 podregionów Polski (NUTS-3) pod względem poziomu uprzemysłowienia jako jednego z elementów oddziałujących na poziom i strukturę rozwoju podregionów. Klasyfikacji dokonano na podstawie danych na temat struktury pracujących i produktywności regionalnej opartej na wartości dodanej brutto. Z uwagi na dostępność danych analizę przeprowadzono na podstawie informacji o aktywności przedsiębiorstw w sekcjach PKD od B do F (łącznie z budownictwem) w latach 2010-2014 oraz dla wybranych aspektów w 2015 r. W badaniu wykorzystano metody klasyfikacji (metodę Warda) oraz porządkowania liniowego (SMR ze wspólnym wzorcem rozwoju). Analiza pozwoliła na wskazanie klas podregionów o określonym profilu rozwoju przemysłu (ogólnym, społecznym bądź gospodarczym) oraz o jednym z typów rozwoju zgodnych z klasyfikacją L. Klaassena (1965).

Wnioski z przedstawionych badań wskazują znaczenie przedsiębiorstw przemysłowych, będącvych regionalnymi pracodawcami (aspekt społeczny) bądź liderami gospodarczymi (aspekt gospodarczy). Z analizy dynamiki zmian wynika, że wzmocnieniu uległa rola przemysłu w podregionach w aspekcie gospodarczym, przy jednoczesnym zmniejszeniu znaczenia w aspekcie społecznym (w niniejszym opracowaniu powiązanym z miejscami pracy).

Słowa kluczowe: przemysł, podregiony (NUTS-3), klasyfikacja, syntetyczna miara rozwoju. 